\title{
Analytical Performances of Nanostructured Gold Supported on Metal Oxide Sorbents for the Determination of Gaseous Mercury
}

\author{
Julien Lusilao-Makiese, ${ }^{1}$ Emmanuel Tessier, ${ }^{2}$ David Amouroux ${ }^{2}$ and Ewa Cukrowska ${ }^{1}$ \\ ${ }^{1}$ School of Chemistry, Molecular Sciences Institute, University of the Witwatersrand, Private Bag Box X3, Wits, \\ Johannesburg 2050, South Africa \\ ${ }^{2}$ Laboratoire de Chimie Analytique, Bio-Inorganique et Environnement (LCABIE-IPREM), UPPA, Hélioparc Pau-Pyrénées, \\ avenue Pdt. Pierre Angot, 64053 Pau Cedex 9, France \\ Correspondence should be addressed to Ewa Cukrowska; ewa.cukrowska@wits.ac.za
}

Received 20 August 2013; Revised 25 February 2014; Accepted 10 March 2014; Published 6 April 2014

Academic Editor: Jan Åke Jönsson

Copyright (C) 2014 Julien Lusilao-Makiese et al. This is an open access article distributed under the Creative Commons Attribution License, which permits unrestricted use, distribution, and reproduction in any medium, provided the original work is properly cited.

\begin{abstract}
Nanostructured gold supported $\mathrm{TiO}_{2}, \mathrm{ZnO}$, and $\mathrm{Al}_{2} \mathrm{O}_{3}$ materials ( $1 \% \mathrm{w} / \mathrm{w} \mathrm{Au}$ ) were tested as sorbents for gaseous mercury ( $\mathrm{Hg}$ ) trapping and preconcentration. Their analytical performances were first compared with the one of traditional gold wool trap for the quantification of $\mathrm{Hg}$ standards injected into the argon flow followed by thermal desorption at $600^{\circ} \mathrm{C}$ and CVAFS detection. Good linearity and reproducibility were obtained, especially for $\mathrm{Au} / \mathrm{TiO}_{2}$ material $\left(R^{2}=0.995\right.$; slope: 1.39$)$ in the volume range of 10 to $60 \mu \mathrm{L}$ (132-778 pg Hg). This latter even showed a better performance compared to pure Au in the volume range of 10 to $100 \mu \mathrm{L}$ $\left(132-1329 \mathrm{pg} \mathrm{Hg}\right.$ ) when the carrier gas flow was increased from 60 to $100 \mathrm{~mL} \mathrm{~min}^{-1}$. The method detection limit (MDL) obtained with $\mathrm{Au} / \mathrm{TiO}_{2}$ trap $\left(0.10 \mathrm{pg} \mathrm{Hg}^{0} \mathrm{~L}^{-1}\right)$ was suitable for total gaseous mercury (TGM) determination. $\mathrm{Au} / \mathrm{TiO}_{2}$ was, therefore, used in trapping and determining TGM in collected air samples. TGM values in the samples ranged from 6 to $10 \mathrm{ng} \mathrm{m}^{-3}$. Similar results were obtained with the commercial gold-coated sand trap which showed an average TGM concentration of $7.8 \pm 0.9 \mathrm{ng} \mathrm{m}^{-3}$.
\end{abstract}

\section{Introduction}

One of the most important environmental oncerns of $\mathrm{Hg}$ is not only its toxicity but also its persistence and long-life in the atmosphere. $\mathrm{Hg}$ from point source emissions may remain localized in the environment or may be transported regionally and even globally [1]. Thus, simple, rapid, sensitive, and selective detection of atmospheric $\mathrm{Hg}$ is required when assessing the potential human health risk from an exposure.

Ambient air may contain considerable amounts of $\mathrm{Hg}$, which are generally present in the elemental form $\left(\mathrm{Hg}^{0}\right)[2,3]$. Sampling and the subsequent analysis of atmospheric $\mathrm{Hg}$, which generally occurs at the femtogram level, is often made as TGM and is performed with highly sensitive detection methods combined with preconcentration techniques [4]. Gold and other precious metals are well known for their high efficiency in trapping $\mathrm{Hg}$ from the gas phase by amalgamation. Therefore, gold based collectors, which are used in many forms such as sand, wool, foil, wire, or deposits on different supports, play an important role in the preconcentration of Hg prior to detection [5-8].

In recent years, the catalytic properties of finely dispersed gold particles on oxide support materials have attracted much attention. Gold was rapidly recognized to be an extremely unique and highly active metal when prepared as supported nanoparticles $[9,10]$. This is mainly due to the reduced dimensions of the gold particles and a strong interaction with the support [11,12]. Thus, supports such as metal oxides are considered to be some of the materials adequate for preparing highly active supported gold catalysts [11]. There is a strong feeling amongst catalyst researchers that in a number of specific areas gold has a potential to be applied commercially, including in pollution control.

Thus, different types of nanostructured gold (or nanogold) materials have been recently tested in many research laboratories as $\mathrm{Hg}$ probes and chemosensors in natural waters $[2,13-17]$ or as oxidation catalysts for $\mathrm{Hg}^{0}$ in flue gases $[18,19]$. 
In this paper, three nanogold supported metal oxides materials $\left(\mathrm{Au} / \mathrm{TiO}_{2}, \mathrm{Au} / \mathrm{ZnO}\right.$, and $\left.\mathrm{Au} / \mathrm{Al}_{2} \mathrm{O}_{3}\right)$ were used for the sampling, preconcentration, and determination of gaseous $\mathrm{Hg}$ and their performances were compared to those of commercially available, namely, gold wool and gold-coated sand, sorbents.

\section{Materials and Methods}

Gaseous Hg was determined by double amalgamation cold vapor atomic fluorescence spectrometry (DA-CVAFS) [20]. Gaseous Hg species were trapped in a first column (sample trap) and desorbed to a second column (analytical trap) at $550-600^{\circ} \mathrm{C}$. This latter usually contains pure gold that allows a more efficient thermal desorption $\left(900^{\circ} \mathrm{C}\right)$ of the analyte to the detector. A transient signal was obtained with an increased signal/noise ratio. Detection limits were, therefore, lowered and the sensitivity was improved. The main advantages of the double amalgamation are found in the preconcentration of $\mathrm{Hg}$ at the second trap and in the reduction of interferences from water vapor and organic compounds during the first thermal desorption [21].

The calibration was done by injecting gaseous $\mathrm{Hg}$ standards directly to the analytical trap. The source of gaseous $\mathrm{Hg}$ was a drop of liquid $\mathrm{Hg}$ contained within a headspace bottle. The Hg drop was in equilibrium with the gaseous phase. A known volume of gas was collected with a microsyringe through a septum. The equilibrium concentration of $\mathrm{Hg}^{0}$ was, therefore, temperature dependent only and was measured with a thermocouple. The relationship between the vapor tension of $\mathrm{Hg}^{0}$ and the temperature is available in the literature [22]. Therefore, the amount of injected $\mathrm{Hg}^{0}$ could accurately be determined.

$\mathrm{Hg}^{0}$ standards were injected and "trapped" using commercial gold wool ( $\mathrm{Au})$, provided by the Laboratoire de Chimie Analytique, Bio-Inorganique et Environnement (LCABIE-IPREM, France), or nanogold supported on metal oxides $\left(\mathrm{Au} / \mathrm{TiO}_{2}, \mathrm{Au} / \mathrm{ZnO}\right.$, and $\left.\mathrm{Au} / \mathrm{Al}_{2} \mathrm{O}_{3}\right)$. The nanogold sorbents pellets were obtained from Mintek (South Africa). The analytical sorbents consisted of $0.1 \mathrm{~g}$ of $1 \%(\mathrm{w} / \mathrm{w})$ gold particles ( $<10 \mathrm{~nm}$ clusters) dispersed on metal oxides support (Figure 1). The sorbents were initially grinded, weighed accurately, and then held securely in a length of quartz tube, which was connected to a temperature controlled heater.

A coil of resistance wire surrounded the quartz tube and was resistively heated with precise temperature control during the analysis step until the coil began to glow dull red.

The trap was heated to release $\mathrm{Hg}$, which was carried to the AFS detector (Tekran 2500, Canada), in a flow of pure argon $\left(60 \mathrm{~mL} \mathrm{~min}^{-1}\right)$. Analytical performances of nanogold materials were first evaluated by injecting $\mathrm{Hg}^{0}$ standards and by comparing the obtained instrument calibration lines to the one of commercial pure gold. A triplicate injection was performed for a given volume of standard for statistical purposes.

The best performing analytical trap among the nanogold sorbents (i.e., $\mathrm{Au} / \mathrm{TiO}_{2}$ ) was later used for the collection of gaseous samples and TGM analysis. The TGM determination

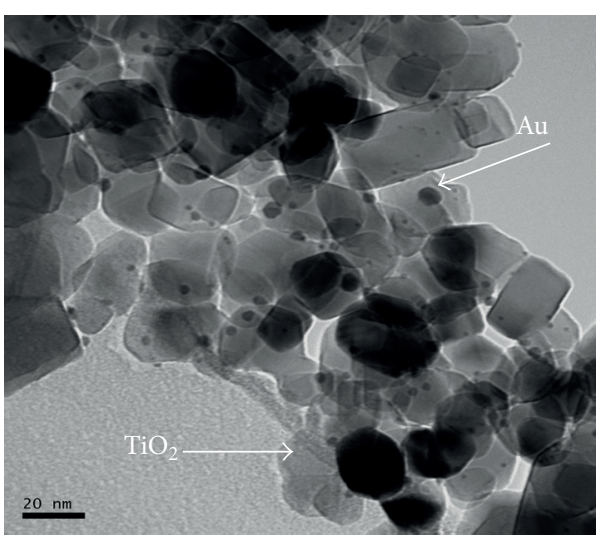

FIgure 1: SEM image of gold particles dispersed on $\mathrm{TiO}_{2}$.

was also carried out by double amalgamation cold vapor AFS (DA-CVAFS) and the performances of nanotraps were compared to those of commercial gold-coated sand traps. A summary of the analytical steps followed for both experiments is shown in Figure 2.

Simultaneous air collection for TGM measurements was done, as shown in Figure 3, with $\mathrm{Au} / \mathrm{TiO}_{2}$ and gold-coated sand traps using a peristaltic pump (ASF THOMAS, Germany). The traps were connected in series to check on collection efficiency. The flow was controlled with a flowmeter (Bronkorst HiTech B.V. E-7000, Netherlands) in order to get an accurate measurement of the sample volume. The air sampling flow was $600 \mathrm{~mL} \mathrm{~min}^{-1}$ and a $0.1 \mu \mathrm{m}$ quartz filter (Whatman) was used to prevent the intrusion of dust and aerosols in the traps. Samples were collected at the ground floor (F1), first floor (F2), second floor (F3), and the roof (R) of the laboratory building.

For the collection of ambient air, a volume gradient was established in order to optimize the sampling time (i.e., the sample volume) and therefore to insure the samples representativity. Short collection times of 10, 20, and $40 \mathrm{~min}$ were used which corresponded to sample volumes of 6,12 , and $24 \mathrm{~L}$ (at a flow of $600 \mathrm{~mL} \mathrm{~min}^{-1}$ ). The air sampler was conditioned every day prior to sampling for stabilization and also for minimizing $\mathrm{Hg}$ adsorption on the walls. Sampling traps were later hermetically closed, stored in a double plastic bag, and analyzed as soon as possible.

It was necessary to perform a quality control before analysis and thus minimize analytical errors that could affect the $\mathrm{Hg}$ determination at such low level (memory effect, contamination, etc.). Therefore, analytical and field blanks were processed through the entire series of sampling and analytical steps which allowed us to determine the different method detection limits (MDL) and the methods limit of quantification (MLQ). Blanks were obtained by either passing UHP grade argon to the traps (analytical blank) or by replacing Whatman filters with the sampling sorbent in the sampling line (field blank). For the latter, the air passing through the sampling trap was, therefore, considered " $\mathrm{Hg}$ free." Field blanks traps were treated in the same way as for actual air samples collection. The resulting "blank" values were subtracted from the analytical results. 


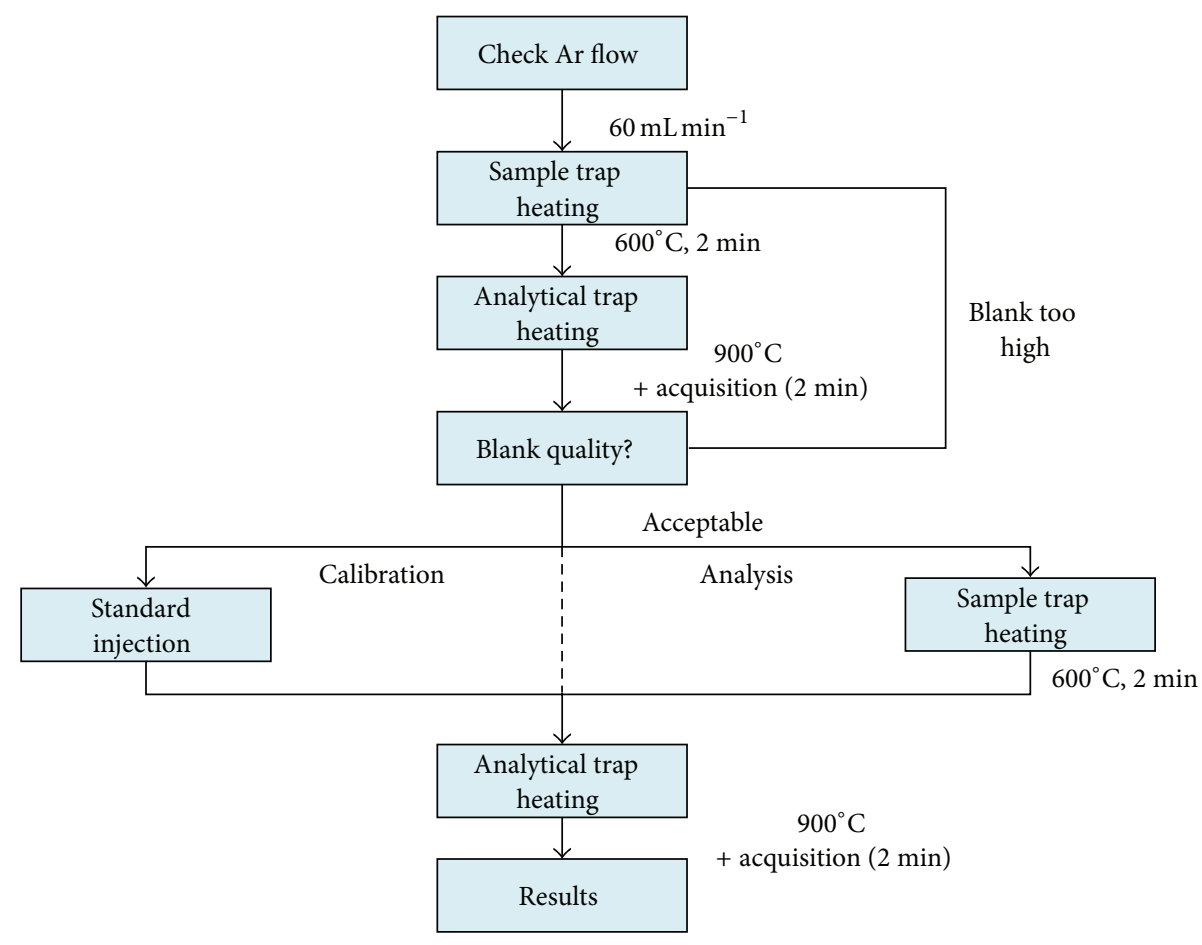

FIGURE 2: Analytical protocols for $\mathrm{Hg}$ standards calibration and TGM analysis.

TABLE 1: AFS signals (area) obtained with $\mathrm{Au} / \mathrm{TiO}_{2}$ trapusing 50 and $100 \mathrm{~mL}$ removable needle syringes (50 $\mathrm{RN}$ and $100 \mathrm{RN}$, resp.).

\begin{tabular}{|c|c|c|c|c|c|c|c|}
\hline \multicolumn{2}{|c|}{ Volume of injected $\mathrm{Hg}^{0}(\mu \mathrm{L})$} & \multicolumn{2}{|c|}{ Temperature $\left({ }^{\circ} \mathrm{C}\right)$} & \multicolumn{2}{|c|}{ Corresponding $\mathrm{Hg}^{0}$ mass $(\mathrm{pg})$} & \multicolumn{2}{|c|}{ Area } \\
\hline $50 \mathrm{RN}$ & $100 \mathrm{RN}$ & $50 \mathrm{RN}$ & $100 \mathrm{RN}$ & $50 \mathrm{RN}$ & $100 \mathrm{RN}$ & $50 \mathrm{RN}$ & $100 \mathrm{RN}$ \\
\hline 5 & 10 & 19.3 & 19.7 & 62.1 & 128.5 & 38 & 145 \\
\hline 5 & 10 & 19.6 & 19.8 & 63.7 & 129.6 & 36 & 140 \\
\hline 5 & 10 & 19.6 & 19.9 & 63.7 & 130.7 & 33 & 140 \\
\hline 10 & 20 & 19.3 & 20.1 & 124.3 & 265.7 & 78 & 362 \\
\hline 10 & 20 & 19.4 & 20.4 & 125.3 & 272.4 & 76 & 320 \\
\hline 10 & 20 & 19.5 & 20.4 & 126.4 & 272.4 & 84 & 350 \\
\hline 20 & 40 & 19.6 & 19.9 & 254.9 & 522.7 & 211 & 750 \\
\hline 20 & 40 & 19.6 & 20.2 & 254.9 & 535.9 & 232 & 754 \\
\hline 20 & 40 & 19.7 & 20.5 & 257.0 & 549.4 & 229 & 797 \\
\hline
\end{tabular}

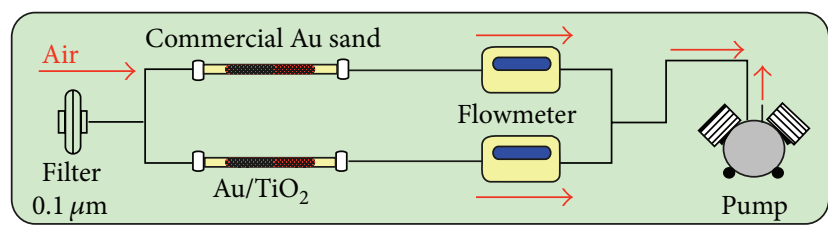

FIGURE 3: Schematic of sampling setup.

\section{Results and Discussion}

3.1. Analytical Performances. An example of signals obtained during analyses is presented in Figure 4.

A good linearity was obtained on the three nanogold materials, especially for $\mathrm{Au} / \mathrm{TiO}_{2}$, in the volume range of $10-60 \mu \mathrm{L} \mathrm{Hg}^{0}$, which corresponds to a concentration range of $131.8-777.5 \mathrm{pg} \mathrm{Hg}^{0}$ at an argon flow of $60 \mathrm{~mL} \mathrm{~min}^{-1}$ (Figure 5). In addition, signals obtained from triplicate injections of $\mathrm{Hg}^{0}$ standards when using $\mathrm{Au} / \mathrm{TiO}_{2}$ as the analytical trap (Table 1) have demonstrated an excellent repeatability with RSD values always below $10 \%$.

Other parameters such as retention time, number of theoretical plates, and full duration at half maximum (FDHM) height also have been studied and are presented in Table 2.

The linearity range of $\mathrm{Au} / \mathrm{TiO}_{2}$ was even improved by increasing the carrier gas flow to $100 \mathrm{~mL} \mathrm{~min}^{-1}$. Calibrations with $\mathrm{Au} / \mathrm{TiO}_{2}$ trap also exhibited a better slope, that is, better analytical response from the detector, under the above conditions compared to the one obtained with gold wool as shown in Figure 6.

It appears, based on the above results, that commercial $\mathrm{Au}$ wool presents the best characteristics: sharp peaks, best 


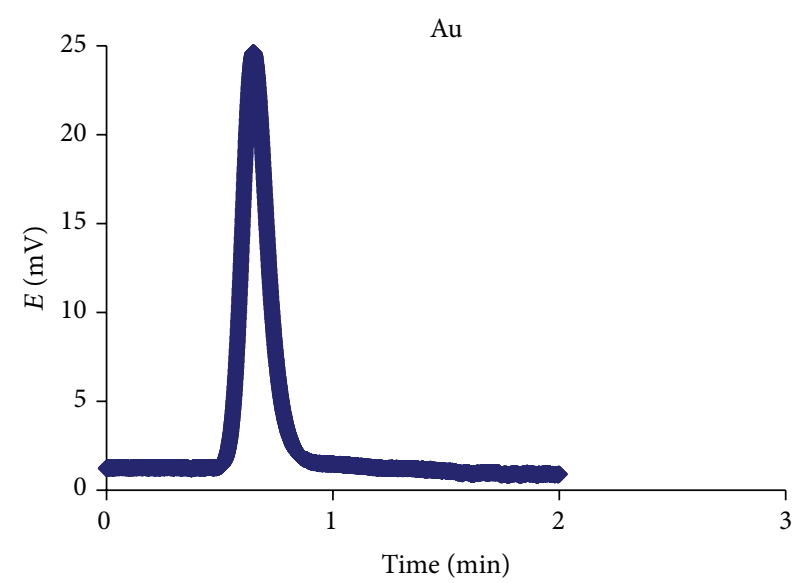

(a)

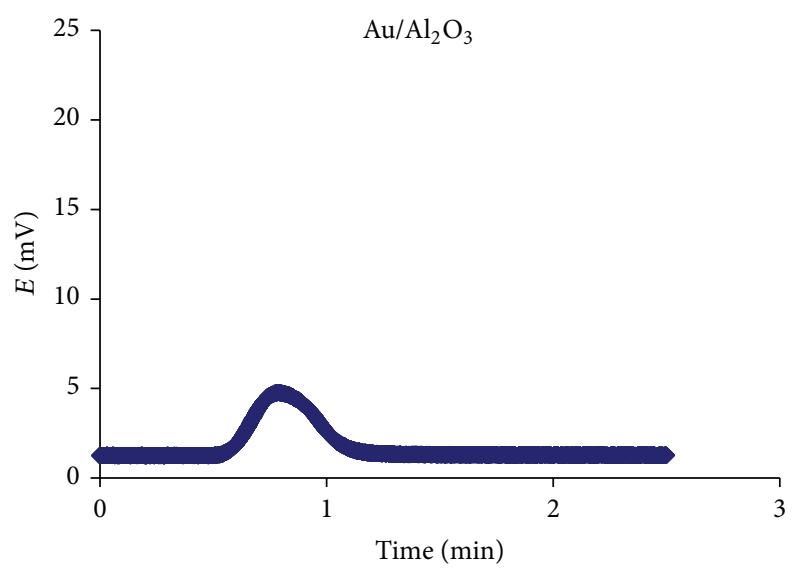

(c)

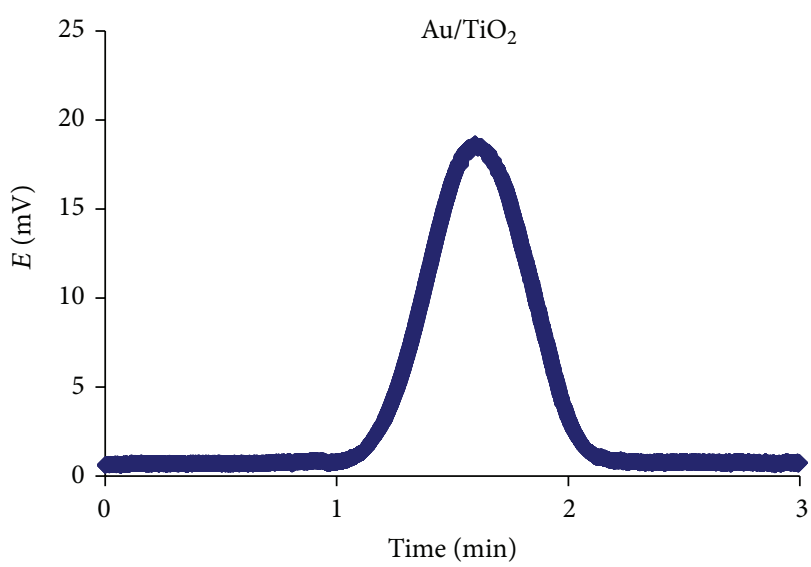

(b)

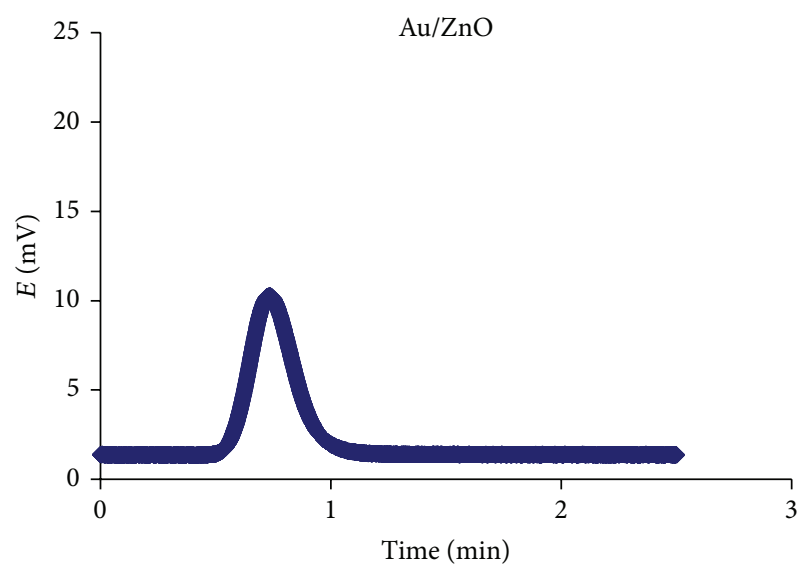

(d)

FIGURE 4: AFS chromatograms of $10 \mu \mathrm{L} \mathrm{Hg}^{0}$ desorbed from different traps.

TABLE 2: Analytical parameters of study materials.

\begin{tabular}{lcccc}
\hline Parameters & $\mathrm{Au}$ & $\mathrm{Au} / \mathrm{TiO}_{2}$ & $\mathrm{Au} / \mathrm{Al}_{2} \mathrm{O}_{3}$ & $\mathrm{Au} / \mathrm{ZnO}$ \\
\hline Retention time (min) & $0.71 \pm 0.05$ & $0.83 \pm 0.03$ & $0.80 \pm 0.01$ & $0.73 \pm 0.01$ \\
Slope $\left(\mathrm{ua} \mathrm{pg}^{-1}\right.$ ) & 1.07 & 1.39 & 0.21 & 0.38 \\
Regression coefficient & 0.997 & 0.995 & 0.988 & 0.986 \\
FDHM (min) & $0.15 \pm 0.01$ & $0.43 \pm 0.06$ & $0.33 \pm 0.03$ & $0.20 \pm 0.01$ \\
Theoretical plates & $136 \pm 7$ & $36 \pm 2$ & $33 \pm 5$ & $69 \pm 3$ \\
\hline
\end{tabular}

regression coefficient, and highest number of theoretical plates. Au wool was, therefore, considered to be the best analytical trap followed by $\mathrm{Au} / \mathrm{TiO}_{2}$.

It is important to notice that, although chromatograms obtained with $\mathrm{Au} / \mathrm{ZnO}$ and $\mathrm{Au} / \mathrm{Al}_{2} \mathrm{O}_{3}$ had retention times similar to the one for $\mathrm{Au}$ wool, these materials showed lower linearity range compared to $\mathrm{Au} / \mathrm{TiO}_{2}$ with lower slopes (Figure 5 and Table 2). They also have demonstrated poor baseline recovery after $\mathrm{Hg}$ desorption (Figure 7).

This implies a great retention of $\mathrm{Hg}$ vapor in the sorbents. Moreover, $\mathrm{Au} / \mathrm{Al}_{2} \mathrm{O}_{3}$ materials exhibited hygroscopic properties (water retention) once exposed to the ambient air. Finally, $\mathrm{Au} / \mathrm{ZnO}$ and $\mathrm{Au} / \mathrm{Al}_{2} \mathrm{O}_{3}$ sorbents have shown different analytical responses (poor reproducibility) when the materials were roughly or finely ground. The difference in analytical performances observed between the nanosorbents could be attributed to the inner structure of the materials used, although this was not investigated in this study.

Numerous experimental and theoretical studies aimed at a better understanding of the properties of gold in the nanometer size regime have suggested that adsorption properties of gold catalysts are deeply influenced by the pore size and specific surface area of the material (see [12] and the references therein). Gold can be present as individual particles in the catalyst or can form agglomerations or clusters. 


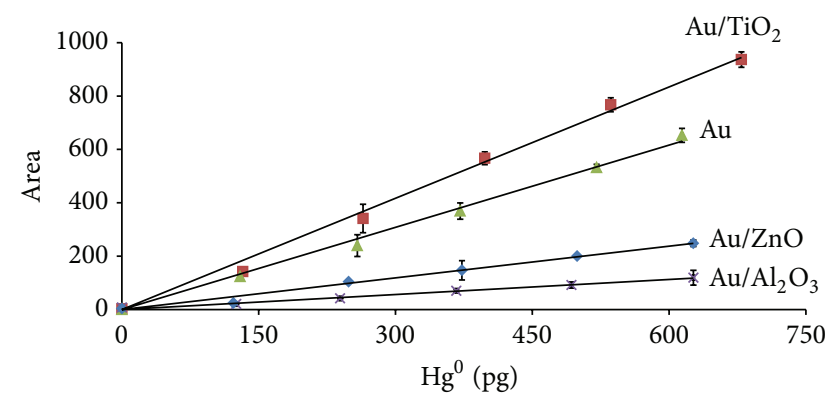

FIGURE 5: AFS calibrations of $\mathrm{Hg}^{0}$ standards at argon flow of $60 \mathrm{~mL}$ $\min ^{-1}$.

The size and the shape of the gold aggregates depend on the temperature and can be metastable once formed at low temperatures. These factors directly affect electronic, optical, and chemical characteristics of nanogold materials. In the case of the ultrathin oxide films, it was shown that the metal substrate lying underneath the film may affect the properties of gold particles, thus leading to an adsorption behavior that depends on the oxide thickness [12]. This could explain the fact that different adsorption capacities were observed with some sorbents (e.g., $\mathrm{Au} / \mathrm{ZnO}$ ), depending on the physical pretreatment.

Finally, studies have also shown that water strongly interacts with oxygen atoms in gold supported metal oxides to make a water-oxygen complex or hydroxyls [23-25], although Quiller and coworkers [26] have suggested that isolated stable hydroxyls may not be formed and could be more transient in character. The susceptibility of nanogold supported metal oxides materials to act as a Brønsted base or a nucleophilic base [27], due to the presence of oxygen atoms, could explain the "wetting" observed with the $\mathrm{Au} / \mathrm{Al}_{2} \mathrm{O}_{3}$ sorbent. A deeper characterization of these materials is, therefore, of importance in order to improve their performance.

It can be seen from the above observations that $\mathrm{Au} / \mathrm{TiO}_{2}$ has demonstrated better analytical performances compared to $\mathrm{Au} / \mathrm{Al}_{2} \mathrm{O}_{3}$ and $\mathrm{Au} / \mathrm{ZnO}$. This is the reason why $\mathrm{Au} / \mathrm{TiO}_{2}$ was selected to be tested as a sampling trap under real environmental conditions.

3.2. TGM Sampling and Determination. As mentioned previously, in order to optimize the air sampling volume, a volume gradient was established using short collection times of 10,20, and $40 \mathrm{~min}$ which corresponded to sample volumes of 6,12 , and $24 \mathrm{~L}$ at a flow of $600 \mathrm{~mL} \mathrm{~min}^{-1}$. The obtained $\mathrm{Hg}$ concentrations (mean value: $6.5 \pm 0.5 \mathrm{ng} \mathrm{m}^{-3}$ ) were all beyond the method analytical performances (see Table 3 ). Due to sample variability caused by the air circulation in the building, the difference in $\mathrm{Hg}$ concentration $( \pm 8 \%)$ for the different sampling volumes was not significant (Figure 8). The optimized sampling time was, thus, chosen to be $20 \mathrm{~min}$, that is, $12 \mathrm{~L}$ in volume.

The obtained methods detection limits (MDL) and methods limit of quantification (MLQ) are shown in Table 3.
TABLE 3: Method analytical performances.

\begin{tabular}{lccccc}
\hline & \multirow{2}{c}{$n$} & \multicolumn{2}{c}{$\mathrm{MDL}\left(\mathrm{ng} \mathrm{m}^{-3}\right)^{*}$} & \multicolumn{2}{c}{ MLQ $\left(\mathrm{ng} \mathrm{m}^{-3}\right)$} \\
& & $\mathrm{Au}$ & $\mathrm{TiO}_{2} / \mathrm{Au}$ & $\mathrm{Au}$ & $\mathrm{TiO}_{2} / \mathrm{Au}$ \\
\hline DA/CVAFS & 10 & 0.07 & 0.10 & 0.22 & 0.33 \\
Sampling & 5 & 0.15 & 0.19 & 0.52 & 0.62 \\
\hline
\end{tabular}

${ }^{*}$ The MDL is calculated for a sample volume of $12 \mathrm{~L}$.

TABLE 4: TGM in the laboratory ambient air where "Au" stands for gold-coated sand.

\begin{tabular}{|c|c|c|}
\hline \multirow{2}{*}{ Sample } & \multicolumn{2}{|c|}{$\mathrm{Hg}\left(\mathrm{ng} \mathrm{m}^{-3}\right)$} \\
\hline & $\mathrm{Au}$ & $\mathrm{Au} / \mathrm{TiO}_{2}$ \\
\hline \multirow{3}{*}{ 1st floor (L1) } & 7.0 & 7.8 \\
\hline & 7.8 & 10.0 \\
\hline & 8.5 & 12.5 \\
\hline Mean \pm SD & $7.8 \pm 0.8$ & $10.1 \pm 2.4$ \\
\hline \multirow{3}{*}{ 2nd floor (L2) } & 6.8 & 6.8 \\
\hline & 8.5 & 7.9 \\
\hline & 9.8 & 8.9 \\
\hline Mean \pm SD & $8.4 \pm 1.5$ & $7.9 \pm 1.1$ \\
\hline \multirow{3}{*}{ 3rd floor (L3) } & 4.8 & 5.1 \\
\hline & 6.2 & 5.9 \\
\hline & 7.9 & 7.0 \\
\hline Mean \pm SD & $6.3 \pm 1.6$ & $6.0 \pm 1.0$ \\
\hline \multirow{3}{*}{ Roof (R) } & 5.8 & 3.2 \\
\hline & 8.3 & 9.2 \\
\hline & 11.6 & 15.0 \\
\hline Mean \pm SD & $8.6 \pm 2.9$ & $9.1 \pm 5.9$ \\
\hline
\end{tabular}

Detection limit values were excellent and suitable for the detection of $\mathrm{Hg}^{0}$ at background level. It has to be recalled that TGM levels for background continental areas were reported to be in the range of 1.0 to $4.0 \mathrm{ng} \mathrm{m}^{-3}[28,29]$.

Results of the TGM measurements performed on the collected air samples from the laboratory environment are presented in Table 4.

TGM concentrations measured with both $\mathrm{Au}$-coated sand and $\mathrm{Au} / \mathrm{TiO}_{2}$ traps were very similar with mean values of $7.8 \pm 0.9 \mathrm{ng} \mathrm{m}^{-3}$ (range: $6.3-8.6 \mathrm{ng} \mathrm{m}^{-3}$ ) and $8.3 \pm$ $2.3 \mathrm{ng} \mathrm{m}^{-3}$ (range: $6.0-10.1 \mathrm{ng} \mathrm{m}^{-3}$ ), respectively. Due to the range of TGM measured and the variability in samples (air recirculation in the building, climate changes, and activities in the laboratory), the obtained values were not considered to be significantly different. Moreover, statistical $t$-test and $F$ test have been used to compare replicates measurements as well as the different standard deviations obtained with both gold-coated sand and $\mathrm{Au} / \mathrm{TiO}_{2}$ traps. Results (Table 5) show that there is no significant difference between both replicates measurements and standard deviations for all the samples. Indoor (L1, L2, and L3) and outdoor (R) concentrations were almost similar, although the variability in $\mathrm{R}$ was higher than in L samples for both traps. This might be caused by changes in environmental conditions during sampling (wind direction and speed, air temperature, point sources, etc.). 
TABLE 5: Statistical results of TGM measurements ( $t$ and $F$ were compared at $95 \% \mathrm{CI}$ ).

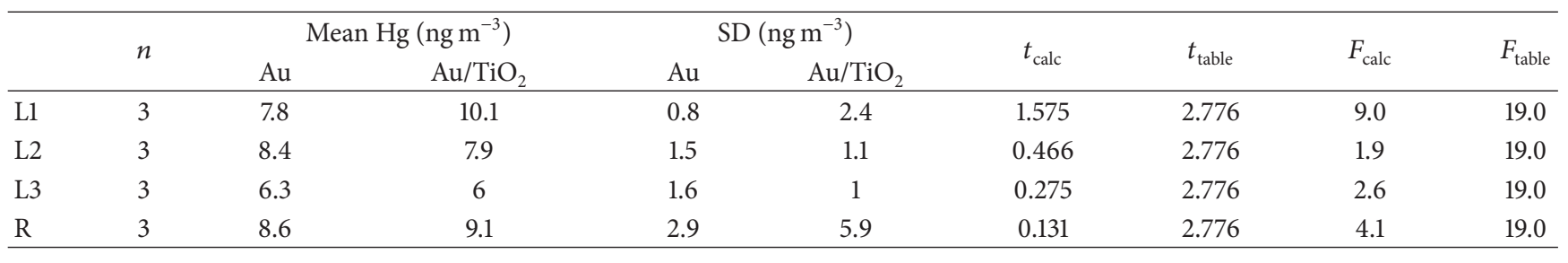

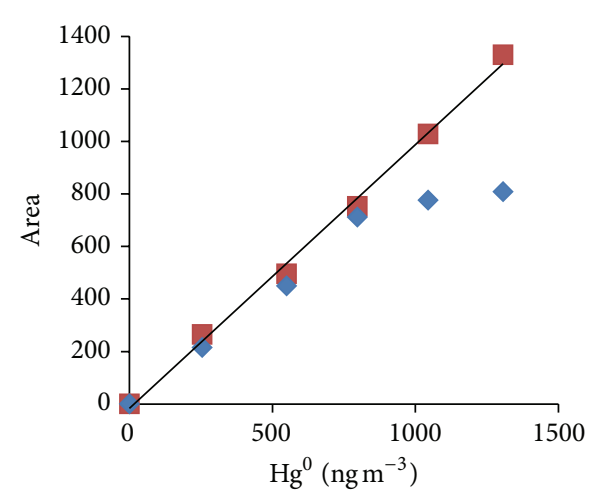

- $100 \mathrm{~mL} / \mathrm{min}$

- $60 \mathrm{~mL} / \mathrm{min}$

(a)

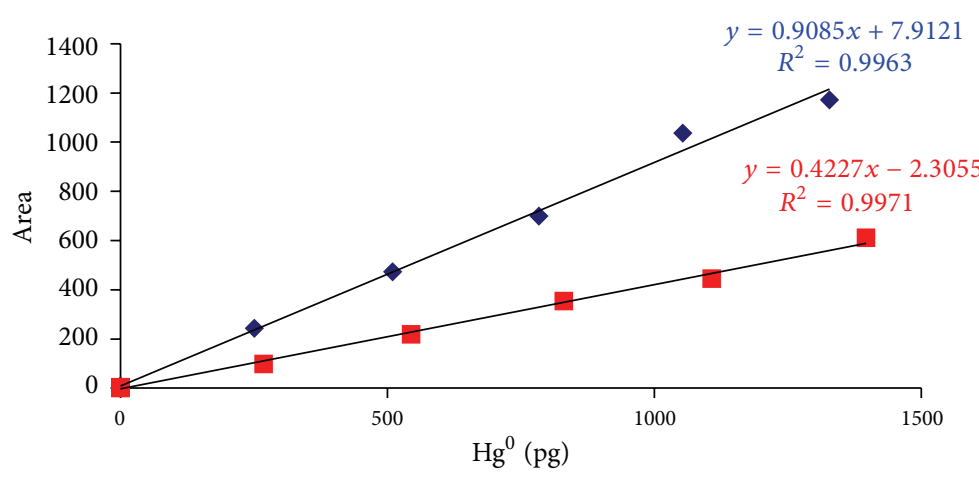

- $\mathrm{Au} / \mathrm{TiO}_{2}$

- $\mathrm{Au}$

Figure 6: Calibrations obtained with $\mathrm{Au}-\mathrm{TiO}_{2}$ at different $\mathrm{Ar}$ flows (a) and with $\mathrm{Au}$ and $\mathrm{Au}-\mathrm{TiO}_{2}$ at $\mathrm{Ar}$ flow of $100 \mathrm{~mL}$ min ${ }^{-1}$ (b).

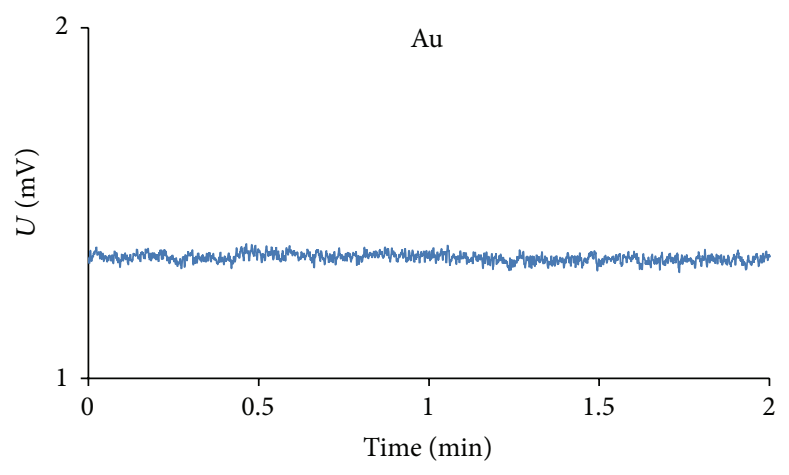

(a)

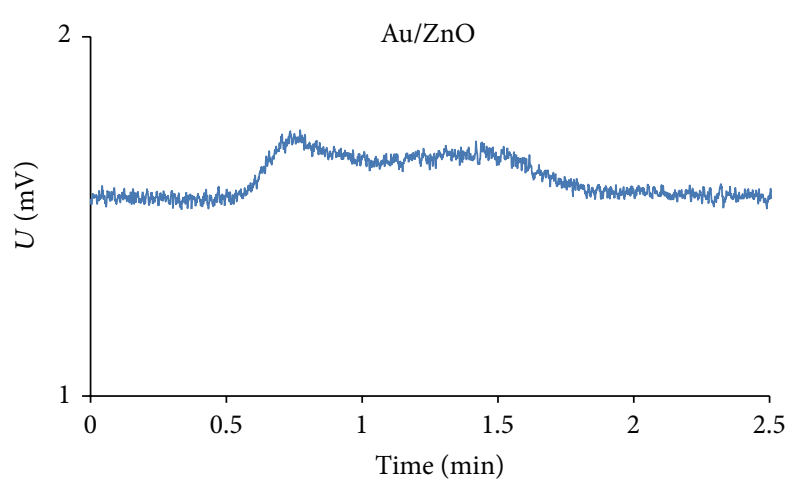

(c)

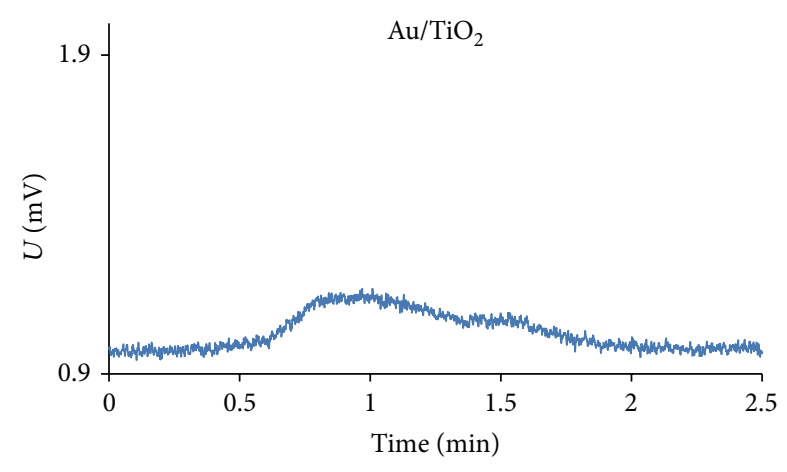

(b)

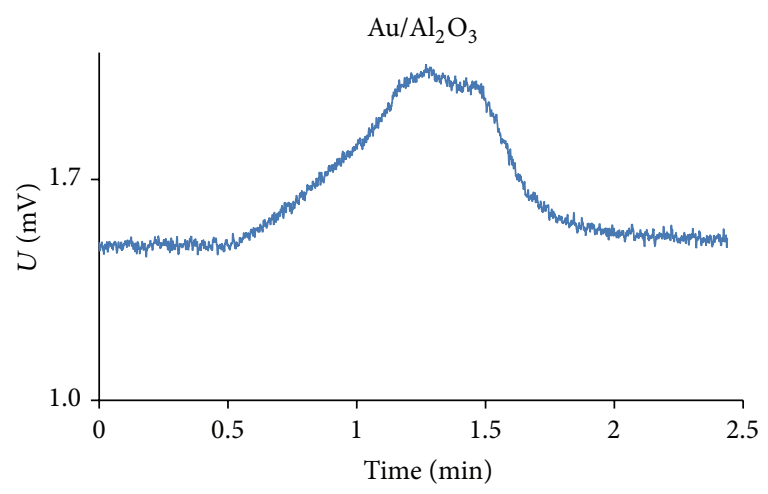

(d)

Figure 7: Examples of baseline obtained after the desorption of $\mathrm{Hg}$ from the different traps. 


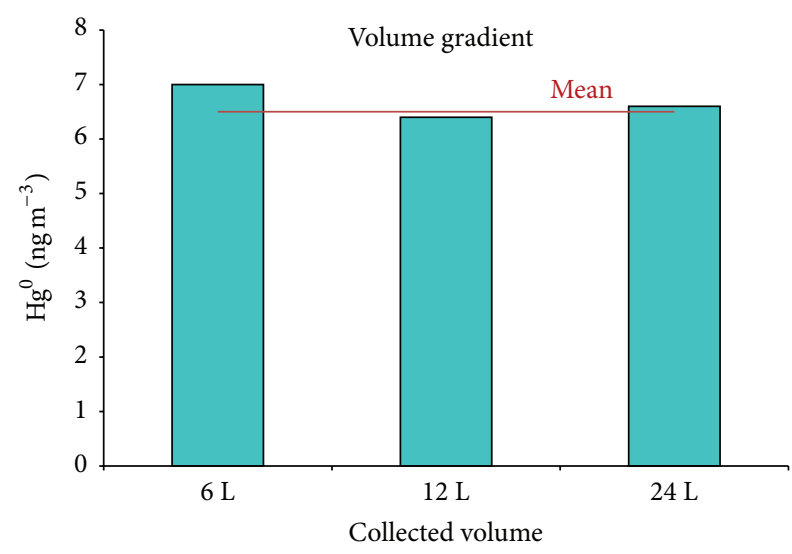

FIgURE 8: Concentrations of $\mathrm{Hg}^{0}$ as a function of sample volume.

It is well known that TGM exhibits an important diurnal variability with generally a maximum peak at midday [30]. The obtained average TGM values were within the range of reported mean TGM concentrations from urban areas [31, 32]. It is important to recall, here, that the collection efficiency of TGM using Au-coated quartz sand has been reported to be $\geq 95 \%$ [33]. Therefore, the closeness of TGM values measured with $\mathrm{Au} / \mathrm{TiO}_{2}$ and the commercial Au-coated sand in the majority of the samples demonstrates the successful application of the nanogold trap under real environmental conditions.

$\mathrm{Au} / \mathrm{TiO}_{2}$ has demonstrated a consistent response after being frequently used for about 3 months depending on storage conditions. A degradation of the adsorption efficiency (drop of signal intensity for a given concentration) was observed when the sorbents were exposed to the light for several hours.

\section{Conclusions}

This study has demonstrated the successful application of nanostructured gold supported in metal oxides materials for the trapping and preconcentration of $\mathrm{Hg}$ directly from the gaseous phase. $\mathrm{Au} / \mathrm{TiO}_{2}$ has shown better analytical performances compared to $\mathrm{Au} / \mathrm{ZnO}$ and $\mathrm{Au} / \mathrm{Al}_{2} \mathrm{O}_{3}$, although it has also exhibited some retention problems. The superior performance of $\mathrm{Au} / \mathrm{TiO}_{2}$ may relate to the grain morphology of $\mathrm{TiO}_{2}$, dispersion of gold particles, and the architecture of metal/oxide junctions.

The excellent MDL obtained with $\mathrm{Au} / \mathrm{TiO}_{2}$ makes it suitable for background TGM determination. Environmental measurements of TGM with $\mathrm{Au} / \mathrm{TiO}_{2}$ were similar to those obtained with traditional gold traps.

The development of an analytical procedure for TGM determination using $\mathrm{Au} / \mathrm{TiO}_{2}$ sorbents was achieved in a performing and cost effective way compared to current methods since only $1 \%(\mathrm{w} / \mathrm{w})$ of gold was required for the preparation of the materials. Finally, a deeper characterization of the inner structure of the studied materials is crucial to understand the different behaviors observed and to improve, where necessary, the performance of the materials.

\section{Conflict of Interests}

The authors declare that there is no conflict of interests regarding the publication of this paper.

\section{Acknowledgments}

The authors thank Mintek (South Africa) for providing the nanosorbents, NRF (South Africa), and CNRS-LCABIEIPREM (France) for funding the project.

\section{References}

[1] US EPA, "Mercury study report to Congress," EPA 452/R-97003, 1997.

[2] Z. Jiang, Y. Fan, M. Chen et al., "Resonance scattering spectral detection of trace $\mathrm{Hg}^{2+}$ using aptamer-modified nanogold as probe and nanocatalyst," Analytical Chemistry, vol. 81, no. 13, pp. 5439-5445, 2009.

[3] W. H. Schroeder and J. Munthe, "Atmospheric mercury: an overview," Atmospheric Environment, vol. 32, no. 5, pp. 809-822, 1998.

[4] J. Munthe, I. Wängberg, N. Pirrone et al., "Intercomparison of methods for sampling and analysis of atmospheric mercury species," Atmospheric Environment, vol. 35, no. 17, pp. 3007-3017, 2001.

[5] W. H. Schroeder, R. Ebinghaus, M. Shoeib, K. Timoschenko, and L. A. Barrie, "Atmospheric mercury measurements in the northern hemisphere from $56^{\circ}$ to $82.5^{\circ} \mathrm{N}$ latitude," Water, Air, and Soil Pollution, vol. 80, no. 1-4, pp. 1227-1236, 1995.

[6] W. H. Schroeder, G. Keeler, H. Kock, P. Roussel, D. Schneeberger, and F. Schaedlich, "International field intercomparison of atmospheric mercury measurement methods," Water, Air, and Soil Pollution, vol. 80, no. 1-4, pp. 611-620, 1995.

[7] T. Labatzke and G. Schlemmer, "Ultratrace determination of mercury in water following EN and EPA standards using atomic fluorescence spectrometry," Analytical and Bioanalytical Chemistry, vol. 378, no. 4, pp. 1075-1082, 2004.

[8] A. Zierhut, K. Leopold, L. Harwardt, P. Worsfold, and M. Schuster, "Activated gold surfaces for the direct preconcentration of mercury species from natural waters," Journal of Analytical Atomic Spectrometry, vol. 24, no. 6, pp. 767-774, 2009.

[9] G. C. Bond and D. T. Thompson, "Catalysis by gold," Catalysis Reviews: Science and Engineering, vol. 41, no. 3-4, pp. 319-388, 1999.

[10] J. Gong and C. B. Mullins, "Surface science investigations of oxidative chemistry on gold," Accounts of Chemical Research, vol. 42, no. 8, pp. 1063-1073, 2009.

[11] B. Zhou, S. Hermanans, and G. A. Sormojai, Nanotechnology in Catalysis, vol. 1-2, Kluwer Academic, Boston, Mass, USA, 2004.

[12] T. Risse, S. Shaikhutdinov, N. Nilius, M. Sterrer, and H.-J. Freund, "Gold supported on thin oxide films: from single atoms to nanoparticles," Accounts of Chemical Research, vol. 41, no. 8, pp. 949-956, 2008.

[13] Z.-Q. Tan and J.-F. Liu, "Visual test of subparts per billion-level mercuric ion with a gold nanoparticle probe after preconcentration by hollow fiber supported liquid membrane," Analytical Chemistry, vol. 82, no. 10, pp. 4222-4228, 2010.

[14] A. Fan, Y. Ling, C. Lau, and J. Lu, "Direct colorimetric visualization of mercury $\left(\mathrm{Hg}^{2+}\right)$ based on the formation of gold nanoparticles," Talanta, vol. 82, no. 2, pp. 687-692, 2010. 
[15] K. Leopold, M. Foulkes, and P. J. Worsfold, "Gold-coated silica as a preconcentration phase for the determination of total dissolved mercury in natural waters using atomic fluorescence spectrometry," Analytical Chemistry, vol. 81, no. 9, pp. 34213428, 2009.

[16] K. Leopold, A. Zierhut, and J. Huber, "Ultra-trace determination of mercury in river waters after online UV digestion of humic matter," Analytical and Bioanalytical Chemistry, vol. 403, no. 8, pp. 2419-2428, 2012.

[17] Y. Gao, Z. Shi, Z. Long, P. Wu, C. Zheng, and X. Hou, "Determination and speciation of mercury in environmental and biological samples by analytical atomic spectrometry," Microchemical Journal, vol. 103, pp. 1-14, 2012.

[18] W. Seames, M. Mann, D. Muggli et al., "Mercury oxidation via catalytic barrier filters: phase II final report," Award no. DE-FG26-04NT42188, Department of Chemical Engineering, University of North Dakota, Grand Forks, ND, USA, 2007.

[19] B.-A. Dranga, L. Lazar, and H. Koeser, "Oxidation catalysts for elemental mercury in flue gases-a review," Catalysts, vol. 2, no. 1, pp. 139-170, 2012.

[20] N. S. Bloom and E. A. Crecelius, "Determination of mercury in seawater at sub-nanogram per liter levels," Marine Chemistry, vol. 14, no. 1, pp. 49-59, 1983.

[21] OSPAR Commission, "JAMP guidelines for the sampling and analysis of mercury in air and pre-cipitation," Monitoring Guideline 1997-8, 1997, http://www.ospar.org/documents/dbase /decrecs/agreements/97-08e.doc.

[22] D. R. Lide, CRC Handbook of Chemistry and Physics, CRC Press, Boca Raton, Fla, USA, 86th edition, 2005.

[23] M. A. Lazaga, D. T. Wickham, D. H. Parker et al., "Reactivity of oxygen adatoms on the $\mathrm{Au}(111)$ surface," in Catalytic Selective Oxidation, vol. 523 of ACS Symposium Series, pp. 90-109, 1993.

[24] T. S. Kim, J. Gong, R. A. Ojifinni, J. M. White, and C. B. Mullins, "Water activated by atomic oxygen on $\mathrm{Au}(111)$ to oxidize $\mathrm{CO}$ at low temperatures," Journal of the American Chemical Society, vol. 128 , no. 19, pp. 6282-6283, 2006.

[25] J. L. Gong, R. A. Ojifinni, T. S. Kim et al., "Low temperature CO oxidation on $\mathrm{Au}(111)$ and the role of adsorbed water," Topics in Catalysis, vol. 44, no. 1-2, pp. 57-63, 2007.

[26] R. G. Quiller, T. A. Baker, X. Deng, M. E. Colling, B. K. Min, and C. M. Friend, "Transient hydroxyl formation from water on oxygen-covered Au(111)," The Journal of Chemical Physics, vol. 129, no. 6, Article ID 064702, 2008.

[27] D. A. Outka and R. J. Madix, "Broensted basicity of atomic oxygen on the gold(110) surface: reactions with methanol, acetylene, water, and ethylene," Journal of the American Chemical Society, vol. 109, no. 6, pp. 1708-1714, 1987.

[28] W. F. Fitzgerald, G. A. Gill, and A. D. Heurot, "Air-sea exchange of mercury," in Trace Metals in Seawater, C. C. S. Wang, E. Boyle, K. W. Bruland, J. D. Burton, and E. D. Goldberg, Eds., pp. 297315, 1984.

[29] O. Lindqvist and H. Rodhe, "Atmosphere mercury-a review," Tellus, vol. 37, no. 3, pp. 136-159, 1985.

[30] D. Amouroux, J. C. Wasserman, E. Tessier, and O. F. X. Donard, "Elemental mercury in the atmosphere of a tropical Amazonian forest (French Guiana)," Environmental Science \& Technology, vol. 33, no. 17, pp. 3044-3048, 1999.

[31] R. Ebinghaus, H. H. Kock, S. G. Jennings, P. McCartin, and M. J. Orren, "Measurements of atmospheric mercury concentrations in Northwestern and Central Europe-comparison of experimental data and model results," Atmospheric Environment, vol. 29, no. 22, pp. 3333-3344, 1995.
[32] C. Pécheyran, B. Lalère, and O. F. X. Donard, "Volatile metal and metalloid species $(\mathrm{Pb}, \mathrm{Hg}, \mathrm{Se})$ in a European urban atmosphere (Bordeaux, France)," Environmental Science \& Technology, vol. 34, no. 1, pp. 27-32, 2000.

[33] W. H. Schroeder, G. Keeler, H. Kock, P. Roussel, D. Schneeberger, and F. Schaedlich, "International field intercomparison of atmospheric mercury measurement methods," Water, Air, and Soil Pollution, vol. 80, no. 1-4, pp. 611-620, 1995. 

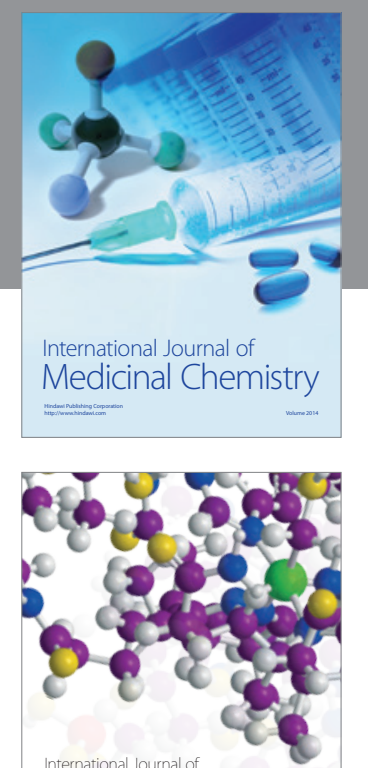

\section{Carbohydrate} Chemistry

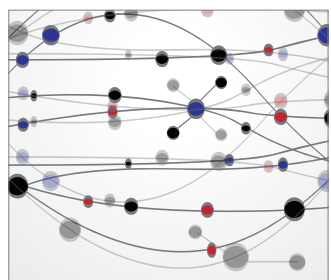

The Scientific World Journal
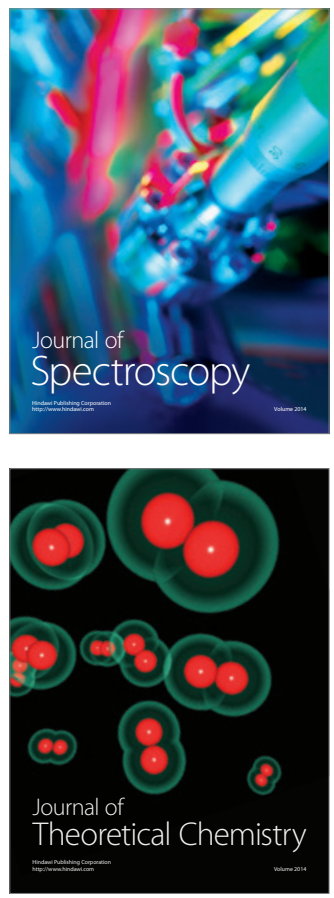
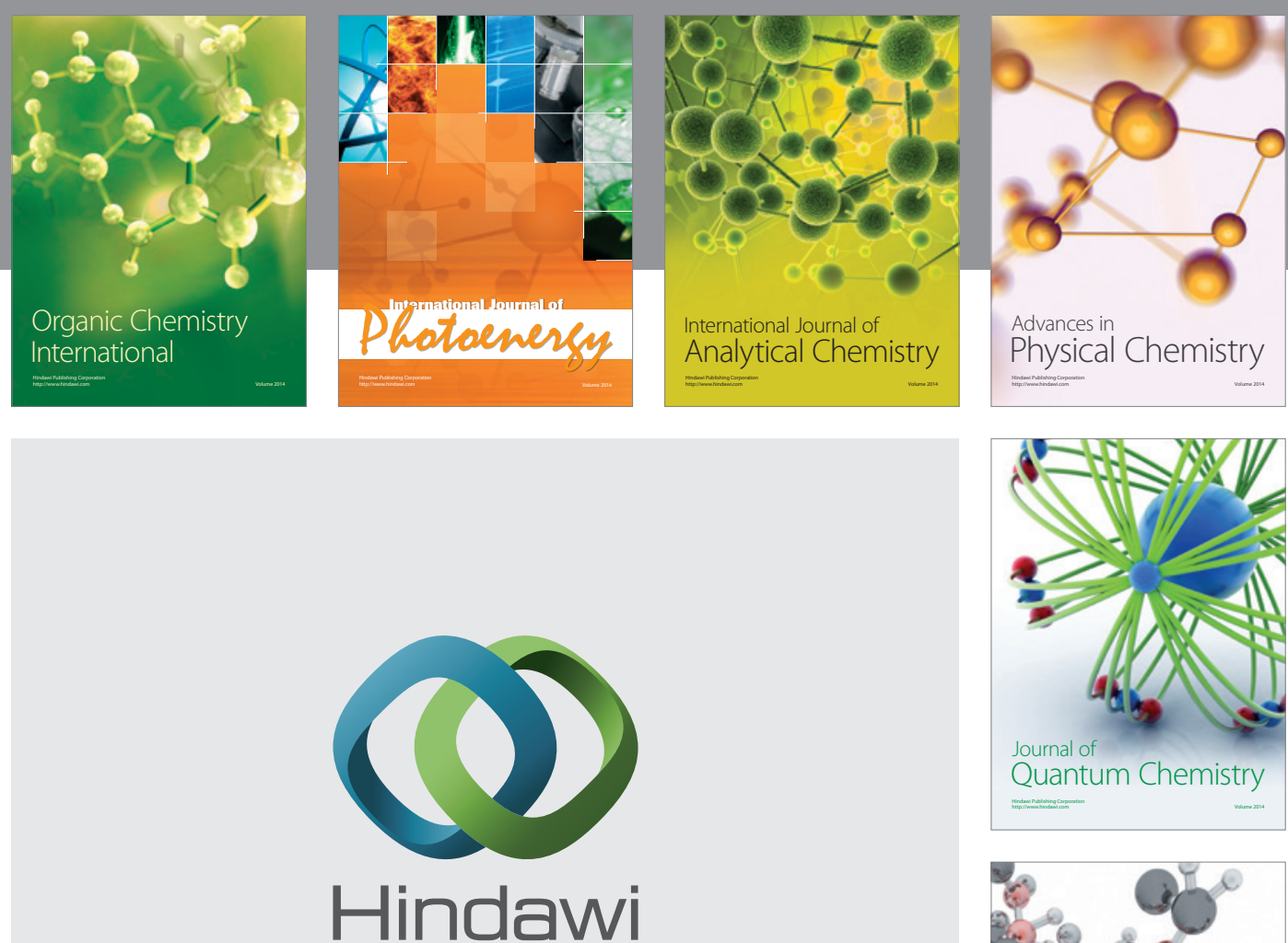

Submit your manuscripts at

http://www.hindawi.com

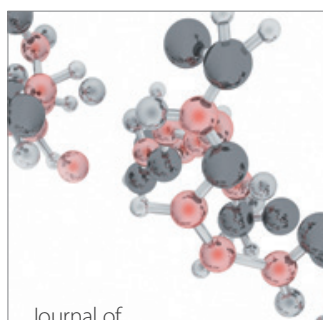

Analytical Methods

in Chemistry

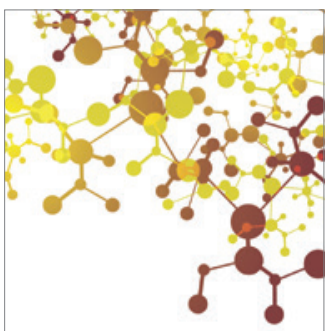

Journal of

Applied Chemistry

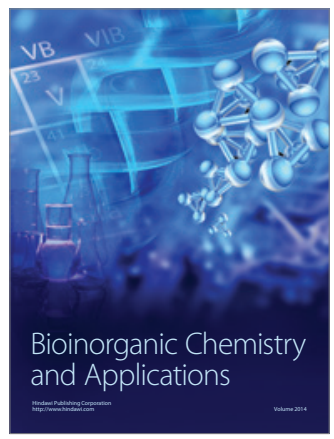

Inorganic Chemistry
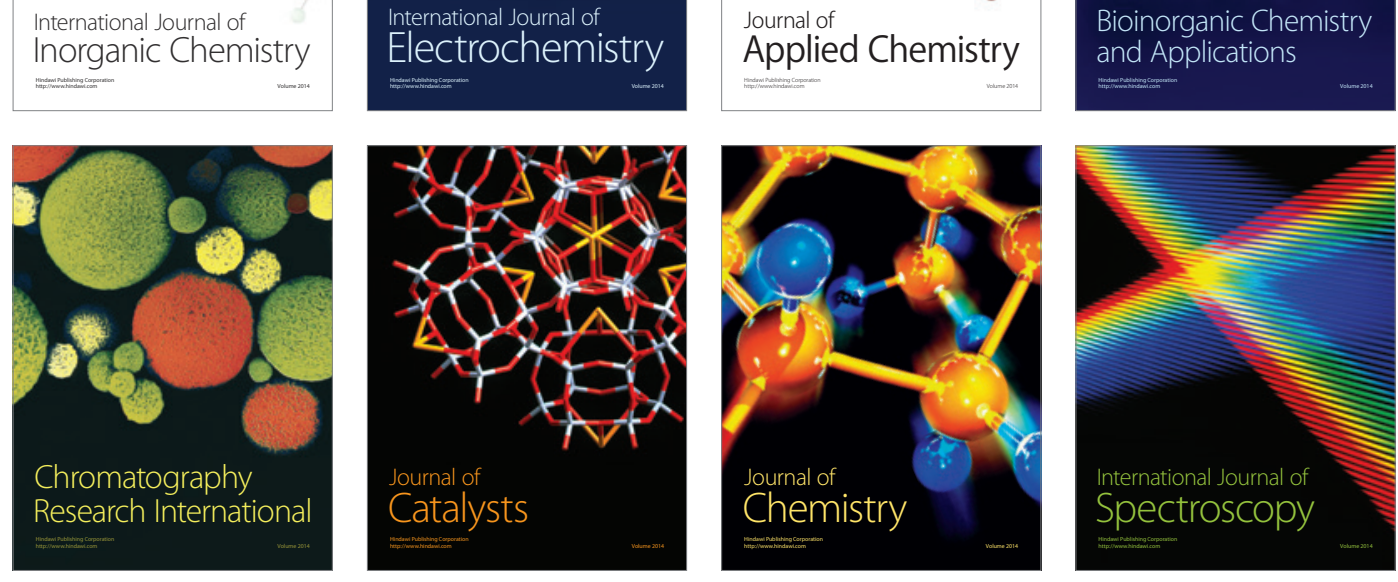